\title{
The Impact of FDI over Economic Growth and how COVID-19 Crisis Can Impact the CEE Economies
}

\author{
Associate Professor Radu CIOBANU, PhD., Professor Robert-Aurelian ŞOVA, PhD., \\ Associate Professor Adriana Florina POPA, PhD. \\ Bucharest University of Economic Studies
}

\begin{abstract}
The purpose if this study was to analyse the impact of FDI inflows on GDP growth and to present if the COVID-19 crisis can impact the CEE economies growth perspective even more than in the current situation. The study confirms that attracting foreign capital is beneficial for an economy, despite the views considering that they may affect the local market. The emergence of foreign companies helps the host country to develop on several levels: the adoption of new technologies and managerial ideas involving human capital, the flows of foreign capital bringing economic benefits, the banking activity development in order to support the financing required by market, governments being forced to adjust legislative measures, and foreign trade being improved. We used a panel data regression model on CEE economies that showed that FDI inflows is highly positively correlated to GDP growth. The results present that all CEE countries can face a higher level of contraction do to the decrease in FDI inflows.
\end{abstract}

Key terms: FDI, COVID-19, CEE economies, fiscal policies

JEL Classification: H12, H61

To cite this article: Radu Ciobanu, Robert-Aurelian Şova, Adriana Florina Popa, The Impact of FDI over Economic Growth and how COVID-19 Crisis Can Impact the CEE Economies, CECCAR Business Review, № 4/2020, pp. 64-72, DOI: http://dx.doi. org/10.37945/cbr.2020.04.08

\section{Introduction}

In line with globalization, trade partnerships between states began to grow. It did not take long until the consequences of trade liberalization appeared, and those who gained from them were those who were aware of the benefits of this phenomenon and succeeded to adapt, creating favorable conditions for the expansion and development of foreign capital investments. Thus, not only has competition been created on the domestic market, forcing local firms to make progress in meeting the new requirements, but there have been numerous benefits at the macroeconomic level. Host countries whose governments have realized the importance of developing certain factors, important for potential foreign investors, have become very attractive for placing foreign direct investments, and the high inflow of FDI is felt through the economic performances achieved. The trend is, fortunately, followed by the developing countries that have become, lately, the main targets for foreign investors.

In the absence of investments, an economy is at a loss, and the public resources allocated to them are often limited as a result of prioritizing national interests towards different directions such as covering the budget deficit or paying salaries and pensions. Thus, the premises of economic development are diminished, and in response to this problem, private financing should be encouraged. Foreign direct investments are not just capital inflows, but a source of long-term stability for an economy. 
The foreign direct investment is a long-term investment relationship between a resident entity and a non-resident entity, which usually involves a significant managerial influence by the investor on the company in which it has invested. The OECD, in the document elaborated to clarify the concept of FDI - The Benchmark Definition of Foreign Direct Investment -, defines foreign direct investments as "a reflection of the objective of obtaining a long-term interest in an entity resident in an economy (called the enterprise of direct investment) by another entity resident in another economy (referred to as a direct investor), implying a long-term relationship between the direct investor and the direct investment firm, as well as a significant degree of investor influence on the management of the receiving enterprise" (https://www.oecd.org/investment/fdibenchmarkdefinition.htm).

In addition to the inflows of capital flows, foreign direct investments also bring technology flows, know-how, managerial ideas and organizational practices, which contribute to stimulating economic growth. Foreign investors impose their own ways of working within the new company, through new technologies and practices, which increase the productivity of the work and the efficiency of the employees, driving the competitiveness of the company. The effects are propagated throughout the entire chain of companies involved in the production of products or services, which need to be adapted to meet new market demands.

Foreign direct investments are usually made in open economies that offer a skilled workforce and above average growth prospects for the investor, as opposed to well-regulated economies. Foreign direct investments often involve more than a capital investment. They often include management or technology provisions, as well. The key feature of foreign direct investment is to establish either effective control or at least substantial influence on the decision-making process of a foreign business.

But in case of crisis there is a problem. The FDI inflows are decreasing, and this can lead to a decrease in the economic growth. In the European Union, the European Commission has warned member states to remain vigilant on foreign direct investment and the movement of capital during the current coronavirus (COVID-19) crisis in an effort to protect strategic industries. "The COVID-19 related emergency is having pervasive effects on the economy of the EU. As part of the overall response, the European Commission also singled out the issue of foreign direct investment screening. Among the possible consequences of the current economic shock is an increased potential risk to strategic industries, in particular but by no means limited to healthcare-related industries", the Commission said in a communication on 25 March. Moreover, member states have been asked to make full use of FDI screening mechanisms to protect the healthcare sector, the supply of critical inputs, as well as other sectors involved in supporting efforts to fight the COVID-19 pandemic.

Do to this fact, the purpose of this article is to assess whether FDI inflows have an impact on the economic growth in CEE countries, and what other factors can also influence this growth. The article is organized as follows. In Section 2 there is an analysis of relevant literature review, in Section 3 the database is explained, Section 4 is related to the results and interpretation, and the last part is dedicated to conclusions.

\section{Literature review}

As for the literature, over time, many hypotheses have been formed regarding the determinants of FDI and how they influence the economy. A positive impact of foreign direct investment on economic growth has been confirmed by a number of studies by researchers, such as Lunn (1980), Schneider and Frey (1985), Carkovic and Levine (2002). Foreign direct investment contributes to economic growth through several channels. First, economic development is expected to be achieved through capital accumulation, the incorporation of more inputs into the production process and the existence of a wider range of intermediary goods (Carkovic and Levine, 2002; Feenstra, 1994). Secondly, FDI is an important source of technological change and improvement of human capital, having the effect of promoting modern technology in the host country (Borensztein et al., 1998). FDI are especially important for economies in transition, because these economies have insufficient reserves, and technology and capital are needed to stimulate economic growth (Billington, 1999; Bevan and Estrin, 2000). International flows of capital, by the magnitude of their structure and stability, are important for the transition to the market economy (Garibaldi et al., 2002, Neuhaus, 2006). 
Moreover, Agarwal and Ramaswami (1992) examined the effect of the interaction between the benefits of firm interactions in terms of export, licensing, joint venture and others. Their results showed the existence of interaction effects, which implies that firms would establish a market in foreign countries through FDI. However, there is a problem as the ability of firms is limited by their size and multinational experience.

Barrel and Pain (1997) draws attention to two important factors: real wage and human capital. They show a strong and inverse link between the evolution of the real wage and the way the FDI unfolds, demonstrating that countries with a lower real wage level are more attractive to foreign investors. Balasubramanyam, Salisu, and Sapsford (1996) conclude with the hypothesis that the share of the active population in the total population (\%) - human capital - is an essential factor in determining both FDI and economic growth, between them there is a strong, positive link.

Government spending is a variable often taken into account in determining FDI and economic growth, being a significant macroeconomic indicator for an economy. Nistor (2014) determines a strong and opposite sign relationship between the two variables. In the same study, a positive correlation between gross capital formation, as part of FDI, and economic growth is expected, a hypothesis confirmed by the significant and positive regression result.

Education is also a variable often found in the models of determining foreign direct investments, given that entering a new foreign investor in the market also implies new managerial ideas and technologies, which require a suitable and better prepared workforce.

Calculated as a percentage of the population with higher education in the total number of educated persons, the education variable is expected to have a positive impact on FDI. The hypothesis is confirmed in Liming Hong's (2013) model, the coefficient of the variable being positive and statistically significant. Also, Borensztein, De Gregorio, and Lee (1998) argue that foreign direct investment has a positive effect on economic growth in countries with a more educated workforce, which accelerates the spread of FDI. On the other hand, Blomstrom, Lipsey, and Zejan (1994) find no evidence that education is a significant factor, arguing that FDI contributes positively to economic growth if the country is rich enough. When it comes to attracting foreign investors, infrastructure and fiscal pressure are the main factors that they analyze when making a decision on the host country of the investment.

Therefore, the more developed the infrastructure, and the more tax-friendly, the more attractive the host economy is for new investments. Infrastructure, measured as the volume of goods transported (tonnes) in relation to the number of roads and highways $(\mathrm{km})$, positively and significantly influences the attraction of FDI, as Shah (2014) shows.

Regarding taxation, the studies clearly show a greater share of foreign direct investments in developing economies, which have adopted attractive and easy legislative measures for the development of new investments, favoring the emergence of foreign investors in the market. The hypothesis is also confirmed by Moran, Graham, and Blomström (2005).

Therefore, the specialized literature confirms the importance of foreign direct investments in the development of an economy, the benefits of which are felt in several areas, all ultimately leading to economic growth. In addition to foreign capital inflows, the host economy benefits from both technological and human progress, through the flows of know-how, organizational practices and managerial ideas that accompany foreign direct investments. Findings on the impact of FDIs inflows in an economy in cases of pandemic crisis are not present in the literature, therefore we have not included other studies here to take into account such a topic.

\section{FDI analysis on CEE economies}

Foreign direct investment and trade are often seen as important catalysts for economic growth especially in CEE countries, representing an important technology transfer tool from the west economies in Europe and, 
also, from US to the East Europe. FDI also stimulates domestic investment and facilitates the improvement of human capital and institutions in the host countries. The size of this impact may vary depending on the country, depending on the level of human capital, domestic investments, infrastructure, macroeconomic stability and trade policies. Following FDI inflows, host countries like the CEE economies, obtain internal benefits in several ways. First of all, GDP growth, initially through foreign direct investment, followed by a positive multiplier effect on the host economy, so that the final increase of national income becomes greater than the initial FDI injection. Second, the internal benefits are produced by creation of jobs and, at the same time, higher wages and improved working conditions. In the end, an increase in FDI increases the demand for the currency of the beneficiary country determining a higher exchange rate. In addition, an increase in a country's currency leads to an improvement in its trading conditions, which is the ratio between export and import prices. However, a larger currency reduces competitiveness and exports may decrease, aggravating the balance of payments. Even so, the positive value of FDI in the balance of payments is more important than any increase in the exchange rate that could follow.

However, the views on FDI are divergent, one of the most debated issues related to foreign direct investments referring to their effects on the economic, financial and social welfare of the host country. Despite the obvious benefits brought by FDI, there are also voices claiming that the multinational firms in a country generate too much dependence of the economy on foreign capital and on the policies of foreign companies, having a detrimental effect on local firms insufficiently prepared for competition. Moreover, if the effects of FDI on an economy are net positive, the question arises by what instruments and to what extent they can be enhanced by the governments of the host countries.

Our database consists of yearly data from Eurostat between 2009 and 2018 for the CEE countries (Bulgaria, Czech Republic, Estonia, Hungary, Lithuania, Latvia, Poland, Romania, Slovenia, Slovakia). In the following figure, we have presented the FDI inflows/GDP (\%) in comparison with the GDP growth rate, as average figures for the CEE countries between 2009 and 2018.

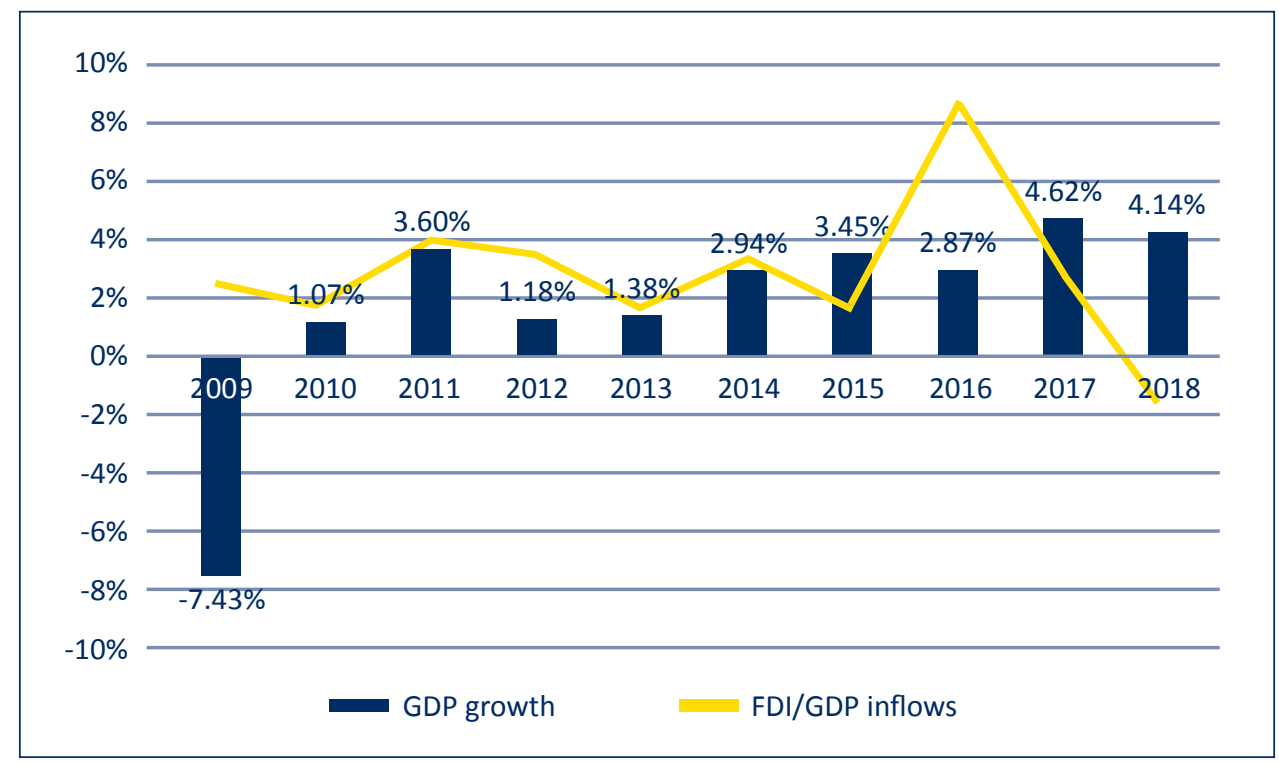

The average GDP growth and average FDI inflows/GDP (\%) for the CEE countries between 2009 and 2018

Source: Eurostat 
In order to analyse the impact of FDI inflow on the GDP growth, we used the date mentioned above and also other variables related to the economic growth such as: country exports, education, labour productivity, labour costs and unemployment. Basically, panel regression models were used to test two hypotheses: the impact of FDI on GDP growth and the impact of other variables on GDP growth. The dependent variables used in the model, as well as their calculation formulas, are presented in Table 1.

Table 1. GDP growth determinants

\begin{tabular}{|l|c|c|l|}
\hline \multicolumn{1}{|c|}{ Variable } & Symbol & Formula & \multicolumn{1}{c|}{ Explanation } \\
\hline $\begin{array}{l}\text { Foreign direct } \\
\text { investment (inflows) } \\
\text { on GDP }\end{array}$ & $\begin{array}{l}\text { FDI(-1) } \\
\text { FDI(-2) }\end{array}$ & $\frac{F D I}{G D P}$ & $\begin{array}{l}\text { FDI inflows in a CEE economy. } \\
\text { We also considered a lag of } \\
-1 \text { and }-2 \text { in order to test the } \\
\text { influence of this variable. (\%) }\end{array}$ \\
\hline $\begin{array}{l}\text { Exports of goods } \\
\text { and services on GDP }\end{array}$ & EXP & $\frac{\text { Exports }}{G D P}$ & $\begin{array}{l}\text { The value of the exports } \\
\text { of goods and services on GDP } \\
\text { in a CEE economy (\%) }\end{array}$ \\
\hline $\begin{array}{l}\text { Education expenses } \\
\text { on GDP }\end{array}$ & EDU & $\frac{\text { Education expenses }}{\text { GDP }}$ & $\begin{array}{l}\text { The value of education } \\
\text { expenses in GDP (\%) }\end{array}$ \\
\hline $\begin{array}{l}\text { Increase in real labour } \\
\text { productivity }\end{array}$ & PROD & $\begin{array}{l}\text { Increase in the productivity } \\
\text { of employees in a CEE } \\
\text { economy (\%) }\end{array}$ \\
\hline Labour costs & LABC & $\begin{array}{l}\text { Labourtivity } \\
\text { hour in a CEE economy (EUR) }\end{array}$ \\
\hline Unemployment rate & UEMPLY & $\begin{array}{l}\text { The employment rate in a CEE } \\
\text { economy (\%) }\end{array}$ \\
\hline
\end{tabular}

Source: Author's own analysis

Further descriptive statistics were presented in order to analyse the key variables for this study (Table 2). During 2009-2018, the GDP growth has an average value of 1.78\%, with a minimum value in Lithuania in 2009 and a maximum value of 7.44\% in Estonia recorded after the crisis of 2008-2010. In terms of FDI inflows/GDP (\%), the average value is $2.71 \%$ with a minimum value of $-46,12 \%$ in Hungary in 2018 , which was a huge disinvestment due to the unstable expectation of the economy and a maximum of $54 \%$ also in Hungary but 2 years before. Education spending to GDP is between $2.8 \%$ and $7.2 \%$ which can indicate a different policy in the CEE countries in this domain. Also, there are major differences in terms of labour costs also, a high value in Czech Republic and Slovakia and low value in Romania and Bulgaria being observed.

Table 2. Descriptive statistics of the determinants of GDP growth in CEE economies

\begin{tabular}{|l|c|c|c|c|c|}
\hline & Average & Median & $\begin{array}{c}\text { Standard } \\
\text { deviation }\end{array}$ & Min & Max \\
\hline GDP growth (\%) & 1.78 & 2.76 & 4.04 & -14.81 & 7.44 \\
\hline FDI inflows/GDP (\%) & 2.71 & 2.82 & 7.90 & -46.12 & 54.22 \\
\hline Export/GDP (\%) & 67.36 & 69.53 & 16.94 & 26.02 & 96.09 \\
\hline
\end{tabular}




\begin{tabular}{|l|c|c|c|c|c|}
\hline & Average & Median & $\begin{array}{c}\text { Standard } \\
\text { deviation }\end{array}$ & Min & Max \\
\hline Education spending/GDP (\%) & 4.95 & 5.10 & 1.03 & 2.80 & 7.20 \\
\hline Increase in real labour productivity (\%) & 4.11 & 3.94 & 4.14 & -10.00 & 13.83 \\
\hline Labour costs (EUR/hour) & 8.19 & 7.85 & 3.37 & 2.60 & 18.10 \\
\hline Unemployment rate (\%) & 9.01 & 8.17 & 3.52 & 2.40 & 19.48 \\
\hline
\end{tabular}

Source: Eurostat

Due to the fact that we have conducted a panel regression models, we had also analyzed the collinearity of the independent variables to avoid any biases of the results (Table 3).

Table 3. Correlation matrix of the independent variables

\begin{tabular}{|l|c|c|c|c|c|c|}
\hline & $\begin{array}{c}\text { FDI/GDP } \\
\text { inflows } \\
\text { (\%) }\end{array}$ & $\begin{array}{c}\text { Export/GDP } \\
\text { (\%) }\end{array}$ & $\begin{array}{c}\text { Education } \\
\text { spending/ } \\
\text { GDP } \\
\text { (\%) }\end{array}$ & $\begin{array}{c}\text { Increase in } \\
\text { real labour } \\
\text { productivity } \\
\text { (\%) }\end{array}$ & $\begin{array}{c}\text { Labour } \\
\text { costs } \\
\text { (EUR/hour) }\end{array}$ & $\begin{array}{c}\text { Unemployment } \\
\text { rate } \\
\text { (\%) }\end{array}$ \\
\hline FDI/GDP inflows (\%) & 1.00 & & & & & \\
\hline Export/GDP (\%) & 0.01 & 1.00 & & & & \\
\hline $\begin{array}{l}\text { Education } \\
\text { spending/GDP (\%) }\end{array}$ & -0.02 & 0.18 & 1.00 & & & \\
\hline $\begin{array}{l}\text { Increase in real } \\
\text { labour productivity } \\
\text { (\%) }\end{array}$ & 0.03 & -0.03 & -0.36 & 1.00 & & \\
\hline $\begin{array}{l}\text { Labour costs } \\
\text { (EUR/hour) }\end{array}$ & -0.05 & 0.47 & 0.47 & -0.13 & 1.00 & \\
\hline $\begin{array}{l}\text { Unemployment } \\
\text { rate (\%) }\end{array}$ & 0.05 & 0.04 & 0.29 & -0.37 & -0.30 & 1.00 \\
\hline
\end{tabular}

Source: Author's own analysis

\section{Results and possible impact of COVID-19 outbreak on FDI and economic growth}

In this section we tested the hypotheses presented in Section 3. As presented in Section 3, we used the panel regression model to analyse whether the FDI inflows have an impact on GDP growth. The study is made on 10 countries, the CEE economies, and we used the values recorded from 2009-2018 on every economy. In order to estimate the influence of FDI, we used lag values for this variable because usually, if a host CEE country will record a FDI inflow this year, the results are expected to be significant in the following years. Due to this fact, we have tested if the FDI(-1) and FDI(-2) can influence the today GDP growth. We considered a fixed effect on cross-section according to the Hausmann Test. The results are presented in Table 4.

The following table estimates which variables influence the economic growth in CEE countries and especially if FDI inflows have an impact on GDP growth. The data is provided by Eurostat. We used a panel regression model with cross-section fixed effects. We did not consider the variables correlated at a higher level than 0.4 in the same regression. T-statistics are in parentheses. The symbols $*, * *, * * *$ represent significance levels of $10 \%, 5 \%$ and $1 \%$. 
Table 4. The model estimated results

\begin{tabular}{|c|c|c|}
\hline \multirow{2}{*}{ Variable } & (1) & (2) \\
\hline \multirow{2}{*}{ FDI(-1) } & $0.02^{*}$ & $0.03^{*}$ \\
\cline { 2 - 3 } & $(1.75)$ & $(1.78)$ \\
\hline \multirow{2}{*}{ FDI(-2) } & $0.05^{* *}$ & $0.05^{* *}$ \\
\cline { 2 - 3 } & $(2.03)$ & $(2.21)$ \\
\hline \multirow{2}{*}{ EXP } & $0.14^{* *}$ & \\
\cline { 2 - 3 } & $(2.41)$ & \\
\hline \multirow{2}{*}{ EDU } & 0.007 & $0.14 * * *$ \\
\hline \multirow{2}{*}{ PROD } & $(0.01)$ & $(2.43)$ \\
\hline \multirow{2}{*}{ LABC } & $0.15^{* * *}$ & 0.03 \\
\cline { 2 - 3 } & $(2.78)$ & $(1.46)$ \\
\hline \multirow{2}{*}{ UEMPLOY } & & 0.04 \\
\hline \multirow{2}{*}{ R-squared } & & $(0.34)$ \\
\hline Number of observations & -0.02 & $\mathbf{3 3 . 4 2 \%}$ \\
\hline
\end{tabular}

Source: Author's own analysis

Our results show that FDI inflows positively influence the GDP growth. The obtained results confirm the expected hypothesis according to the specialized literature: foreign direct investments positively influence the economic growth, the variable being statistically significant, at a significance threshold of $5 \%$ or $10 \%$. In other words, the higher the inflow of FDI is, the more the host economy will grow. The model presents that a higher significance level is recorded in terms of FDI(-2), which can suggest that usually, in CEE countries, the impact of FDI on economic growth is expected with a 2 years delay.

Foreign direct investments are particularly important for CEE economies, as they are deficient in terms of reserves, technology and capital being needed to stimulate economic growth. International flows of capital, by the magnitude of their composition and stability, are important for the transition to the market economy. After receiving foreign capital, the host countries registered an increasing trend in terms of growth rates in the period 2012-2017. To a considerable extent, this growth can be explained by FDI inflows that contribute to the development of the host economy through the use of new technologies, knowledge, employment growth and the opening of new markets.

Given the transfer of innovation and technology brought by FDI, human capital plays an important role in this process, the effects of FDI on the economy of the host country depending on the stock of human capital. The model shows a positive correlation between the two, the labour productivity being statistically significant at a significance threshold of $1 \%$ related to the economic growth. In other words, with the entrance of FDI companies in a country, competition for the labor force increases considerably, also due to the impact of the human factor. 
Related to the FDI inflows are also the exports which resulted to be influencing the GDP growth. Our results show a positive correlation. The relationship between GDP growth and the education system is still a topic under debate, the specialized literature reporting very diverse conclusions in this regard. As a social factor, education is considered to have a positive impact on economic growth. However, after testing the panel with fixed effects, the obtained results invalidate the hypothesis. The same inconsistent results are with labour costs and unemployment.

As our results show there is a strong correlation between FDI inflows in CEE countries and GDP growth. In the current COVID-19 crisis, there is a high expectation that a decrease in the FDI inflows can help also the GDP growth reduction and bring the economies to recessions. At the United Nations Conference on Trade and Development (UNCTAD) a forecast about the impact of the COVID-19 pandemic on global foreign direct investment flows was conducted and it is anticipated that there could be a drop of between $30 \%$ and $40 \%$ in 2020, a trend that would persist into 2021. We expect an even high level to be recorded in CEE economies, that will make them very hard to recover from the current crisis. Also, due to the fact that in these countries a lot of multinational companies are present, the spread of coronavirus will impact and downward revisions of the earnings.

Early expectations that the impact would be felt primarily through production stoppages and supply chain disruptions in East Asia and, particularly, China, but nowadays it is affecting all economies in the world, because all countries are integrated into global supply chains, and the CEE countries are a part of this as well. In one word, CEE countries are preparing for the worst. The EU Commission baseline is likely to project that these countries will face a contraction in 2020 of 3-5\%. A 'worst case' scenario with contractions of $10 \%$ or more is however less possible due to the European funds help.

\section{Conclusions}

Following the analysis, two conclusions can be drawn: one on the existence of the impact of foreign direct investment on the economic growth and another one on FDI flows decrease due to COVID-19 crisis which can lead to a contraction in CEE economies. Thus, the study confirms that attracting foreign capital is beneficial for an economy, despite the views that it may affect the local market. The emergence of foreign companies helps the host country to develop on several levels: the adoption of new technologies and managerial ideas involving human capital, the flows of foreign capital bringing economic benefits, the banking activity development in order to support the financing required by market, governments being forced to adjust legislative measures, and foreign trade being improved.

Factors influencing GDP growth have varied over time depending on the changes that have occurred as a result of the globalization phenomenon. While the literature shows the importance of infrastructure, financial intermediation or gross capital formation from the perspective of investors, the study shows that during 2009-2018 the FDI inflows have an important thing to say. Therefore, FDI's contribution to economic growth is unquestionable, due to the contribution of technology, know-how, innovation and capital. However, capital mobility is a feature that must be taken into account, with a permanent concern regarding capital outflows, for attracting new foreign resources and to maintain the level of well-being. In order to preserve, amplify and attract new FDI, two directions can be considered: adoption of measures to increase the absorption capacity of the economy and implementation of strategies to attract foreign investors.

But, in case of COVID-19 crises, there is a problem. The FDI inflows are decreasing, and this can lead to a decrease in the economic growth and even turn into a recession period for the CEE countries. As we already 
mentioned, in the European Union, the European Commission warned the member states to remain vigilant on foreign direct investment and the movement of capital during the current coronavirus (COVID-19) crisis in an effort to protect strategic industries. Therefore, we expect that CEE countries governments to adapt to this new macroeconomic conditions and find ways to stimulate FDI inflows in the nearer future.

\section{Bibliography}

1. Agarwal, S., Ramaswami, S.N. (1992), Choice of Foreign Market Entry Mode: Impact of Ownership, Location and Internationalization Factors, Journal of International Business Studies, Vol. 23, No. 1, pp. 1-27.

2. Balasubramanyam, V.N., Salisu, M., Sapsford, D. (1996), Foreign Direct Investment and Growth in EP and IS Countries, Economic Journal, Vol. 106, No. 434, pp. 92-105.

3. Barrel, R., Lansbury, M., Morgan, J., Pain, N. (1997), Job Creation in the US and Europe Compared, Labour Market Trends, May, pp. 173-174.

4. Bevan, A.A., Estrin, S. (2000), The Determinants of Foreign Direct Investment in Transition Economies, Centre for New and Emerging Markets, Discussion Paper No. 2.638.

5. Billington, N. (1999), The Location of Foreign Direct Investment: An Empirical Analysis, Applied Economics, Vol. 31, No. 1, pp. 65-76.

6. Blomstrom, M., Lipsey, R.E., Zejan, M. (1994), What Explains the Growth of Developing Countries?, Convergence of Productivity: Cross-National Studies and Historical Evidence, pp. 243-259.

7. Borensztein, E., De Gregorio, J., Lee, J.-W. (1998), How Does Foreign Direct Investment Affect Economic Growth?, Journal of International Economics, Vol. 45, No. 1, pp. 115-135.

8. Carkovic, M., Levine, R. (2002), Does Foreign Direct Investment Accelerate Economic Growth?, Working Paper, University of Minnesota, pp. 195-220.

9. Feenstra, R.C. (1994), New Product Varieties and the Measurement of International Prices, The American Economic Review, Vol. 84, No. 1, pp. 157-177.

10. Garibaldi, P., Mora, N., Sahay, R., Zettelmeyer, J. (2002), What Moves Capital to Transition Economies?, Working Paper No. 2-64, International Monetary Fund.

11. Hong, L. (2013), Does and How Does FDI Promote the Economic Growth?

12. Lunn, J. (1980), Determinants of US Direct Investment in the EEC: Further Evidence, European Economic Review, Vol. 13, No. 1, pp. 93-101.

13. Moran, T.H., Graham, E.M., Blomström, M. (Editors) (2005), Does Foreign Direct Investment Promote Development?, Columbia University Press.

14. Neuhaus, M. (2006), The Impact of FDI on Economic Growth: An Analysis for the Transition Countries of Central and Eastern Europe, Springer Science \& Business Media.

15. Nistor, P. (2014), FDI and Economic Growth, the Case of Romania, Procedia Economics and Finance, Vol. 15, pp. 577-582.

16. Schneider, F., Frey, B.S. (1985), Economic and Political Determinants of Foreign Direct Investment, World Development, Vol. 13, No. 2, pp. 161-175.

17. Shah, M.H. (2014), The Significance of Infrastructure for FDI Inflow in Developing Countries, Journal of Life Economics, Vol. 1, No. 2, pp. 1-16.

18. https://www.oecd.org/investment/fdibenchmarkdefinition.htm 